\title{
The Conservation of Ground Water Levels in the Peat Swamp Forest at Ayer Hitam North Forest Reserve, Muar in Johor, Malaysia
}

\author{
Siti Aisah Shamsuddin', Mohd Azahari Faidi1, Hyrul Izwan Mohd Husin1, \\ Mohamad Fakhri Ishak ${ }^{2}$, Ismail Parlan³ ${ }^{3}$ Habsah Marjuni ${ }^{4}$ \\ ${ }^{1}$ Forestry \& Environment Division, Forest Research Institute Malaysia, Kepong, Selangor, Malaysia \\ ${ }^{2}$ Forest Biotechnology Division, Forest Research Institute Malaysia, Kepong, Selangor, Malaysia \\ ${ }^{3}$ Director General, Forest Research Institute Malaysia, Kepong, Selangor, Malaysia \\ ${ }^{4}$ Yayasan Kemanusiaan Muslim Aid Malaysia, Menara Mutiara Bangsar, Jalan Liku Off Jalan Riong, Kuala Lumpur, Malaysia \\ Email: sitiaisah@frim.gov.my, azaharifaidi@frim.gov.my, hyrulizwan@frim.gov.my, mohamadfakhri@frim.gov.my, \\ ismailp@frim.gov.my, hmarjuni@gmail.com
}

How to cite this paper: Siti Aisah, S., Mohd Azahari, F., Hyrul Izwan, M.H., Mohamad Fakhri, I., Ismail, P. and Habsah, M. (2021) The Conservation of Ground Water Levels in the Peat Swamp Forest at Ayer Hitam North Forest Reserve, Muar in Johor, Malaysia. Journal of Water Resource and Protection, 13, 957-975.

https://doi.org/10.4236/jwarp.2021.1312052

Received: October 9, 2021

Accepted: December 10, 2021

Published: December 13, 2021

Copyright $\odot 2021$ by author(s) and Scientific Research Publishing Inc. This work is licensed under the Creative Commons Attribution International License (CC BY 4.0).

http://creativecommons.org/licenses/by/4.0/

\begin{abstract}
The management of peat swamp forests in Malaysia contends with two major issues: forest fires and the effects of abandoned forest-logging drainage systems or canals. Forest fire occurs during low rainfall season related to the local people activities. The drainage networks change the hydrological function of the intact forest ecosystem. A key function of the hydrological system in the undisturbed forest is to absorb water during rainfall season, thus delaying downstream runoff and preventing flash floods. The objective of the project described here is to restore the hydrological function of peat swamp forest (PSF) at Ayer Hitam North Forest Reserve (AHNFR) in Muar, Johor, Malaysia. The oil palm plantations, especially in the southern part of the area affect the forest reserve. Water flows out of the forest reserve through the drainage system constructed for managing these plantations. In 2016 and 2017, two water block structures or check dams were constructed near the boundaries of the forest reserve to hold the water and raise the groundwater level in the forest reserve. The implementation of the check dams at the two locations has conserved the groundwater level and subsequently, about 1.2 million $\mathrm{m}^{3}$ of water was saved annually from leaving the forest reserve from each of the check dam. This project is also part of the Coca-Cola Company's sustainability commitment for water strategy with the global that is to replenish $100 \%$ of the equivalent volume of water consumed in their products and production by 2020 . Replenishment is the key sustainability commitment for the Company.
\end{abstract}




\section{Keywords}

Hydrology, Oil Palm Plantation, Water Blockage, Peat Swamp Forest, Ground Water Level Conservation

\section{Introduction}

In 2010, peatlands covered about 2.46 million hectares in Malaysia [1] [2], in which the states of Selangor, Pahang, and Sarawak have the largest peatland areas. Of the total, Peninsular Malaysia has 0.25 million hectares [3] of peatland swamp forests (PSF), while another 0.31 million hectares are located in Sarawak. In Peninsular Malaysia, most of the PSFs are located in the low-lying plains, inland of the mangrove and coastal ridge forest. On the west coast, peat occurs on coastal alluvial clay, while on the east coast it occurs on the coarse sand immediately behind beach ridges. PSF can be categorized as ombrogenous or topogenous. Rainfall intensity and frequency influenced the groundwater level close to or above the peat surface throughout the year.

PSF not only contributes a commercially valuable timber, but also supports a biodiverse system of endemic flora and fauna [4]. This forest provides substantial organic carbon storage and is also of socio-economic value to the local communities. It also performs important hydrological functions: it delays precipitation runoff downstream and thus prevents floods during the rainy season; and its high-capacity water absorption helps the forest endure the dry season. In Peninsular Malaysia, the North Selangor peat swamp forest (NSPSP) drainage system facilitates agricultural activities, primarily rice planting in the Sekinchan district in the State of Selangor [5].

PSFs typically have poor drainage and are permanently waterlogged, although the extent of these features depends on rainfall levels and topography. Waterlogging decreases the decomposition of organic matter from plant litter. Additionally, most of Malaysia's lowland peatlands have developed along the coast behind accreting mangrove coastline, where sulfides in mangrove mud and water restrict bacterial activity and lead to the accumulation of organic matter as peat. Peat is typically $0.5 \mathrm{~m}$ deep; however, it can reach $20 \mathrm{~m}$ deep, as has been recorded in Sarawak PSF [6]. The vegetation profile of PSF is less complex than that of lowland dipterocarp forests. A peat soil is $90 \%$ organic matter and is highly acidic, with $\mathrm{pH}$ levels as low as 3.5 .

In a natural and undisturbed peat swamp forest, a dense canopy cover protects the soil surface and prevents the solar radiation from reaching the soil and limits the air movement below the canopy. Under this condition, peat soil maintains a high degree of moisture, which prevents the decay process from initiating [7].

In Malaysia, the management of PSF must address the negative impacts of certain human activities in the forests: the risk of forest fires, the impact of forest 
harvesting, and land changes related to agriculture and plantations. The construction of drainage canals to transport logs during forest harvesting has had several adverse effects [8] [9]. The canals were abandoned after forest harvesting activities ended, but they have continued to be the primary cause of water drainage from the PSF reserve. The canals increase the flow of water out of the forest, leading to subsidence, soil compaction, and greater risk of forest fires. Several of the worst forest fire episodes in Malaysia occurred in the North Selangor PSF in the 1970s and 2000s after the forest reserve had been involved in forest-logging operation. The conversion of PSF to agricultural uses has also created problems. Land preparation for oil palm plantations, such as clearing and the construction of drainage systems, increases the flow of water out of the forest and affects the groundwater level. These activities cause the surface peat layer to dry out, leading to peat subsidence and increasing the forest's susceptibility to fire. Reference [10] studied in tropical peatland of Central Kalimantan found that to prevent subsidence or fire, the groundwater levels should be maintained between $40 \mathrm{~cm}$ below and $100 \mathrm{~cm}$ above the peat surface. The process of subsidence starts as soon as peat swamp is drained and this process can only be stopped by rewetting the areas. It has been reported that $60 \%$ of peat subsidence is caused by oxidation and $40 \%$ by irreversible drying or shrinkage of the peat [10] [11].

Hydrological restoration is a key component in the rehabilitation of PSF degraded by drainage and drying. Blocking the excessive outflow of water will slowly raise groundwater levels, increasing the moisture in the peat and thus reducing the risk of forest fires. This study implements hydrological management measures to increase and maintain PSF groundwater level. The establishment of plantation drainage systems has depleted the groundwater level and continuous outflow from the forest reserve. The objectives of the project are to establish water block structures, increase water level of the drainage and reduce the flow rate from the forest reserve.

\section{Site Description}

Ayer Hitam North Forest Reserve (AHNFR) is located in the Muar district, in Johor state of Peninsular Malaysia at latitude 2.057427 and longitude 102.806116). This forest is the largest forest reserve, which covers 3797 hectares (ha) and the last peat swamp forest (PSF) can be found in this state. Apart from that, AHNFR is the only peat swamp forest recognized as Forest State Park in Peninsular Malaysia. This protected forest is threatened by forest fires and encroachment of the local people activities related to small farming activities at the border of the forest reserve and trespassing without the authority's concern.

Based on a 2015 land use map (Landsat 8 ETM) produced by the satellite image interpretation, land uses in AHNFR are categorized as peat swamp forest, inland forest, open land (i.e., the roads and the Tenaga National Berhad power line), shrub areas (ex-burned and encroached areas), water bodies, and others 
(ex-mining area). The AHNFR is developed between three river systems that is Muar River in the northwest, Sarang Buaya River in the south and Batu Pahat River in the southeast (Figure 1).

Small-holder agricultural lands and oil palm plantations have been developed since the 1700s surrounding the peatlands of AHNFR. These activities include the creation of many drainage systems to lower the groundwater level, which changes the natural formation of peat deposits. Additionally, opening the forest canopy dries out the soil surface, consequently changing the properties of the peat soil. Reference [12] reported that 81 hectares from the 3797 hectares of forest reserves have been subsided because of human activities for the last 45 years. The soil sinking at each foot of the TNB's power line tower demonstrates the soil subsidence. In 2021, measurements taken at each foot indicated that the average reduction of the soil from as deep as $89.4 \mathrm{~cm}$ at the lower part of the peat soil land area to $30.0 \mathrm{~cm}$ toward the mineral soil land areas in the forest reserve. Reference [12] also forecasted through simulation model the impact of subsidence could reach 1886 hectares in the next 25 years and 2350 hectares in the next century. A sufficient buffer zone is necessary to protect further deterioration of the forest reserve. It has been 10 years since the findings occur.

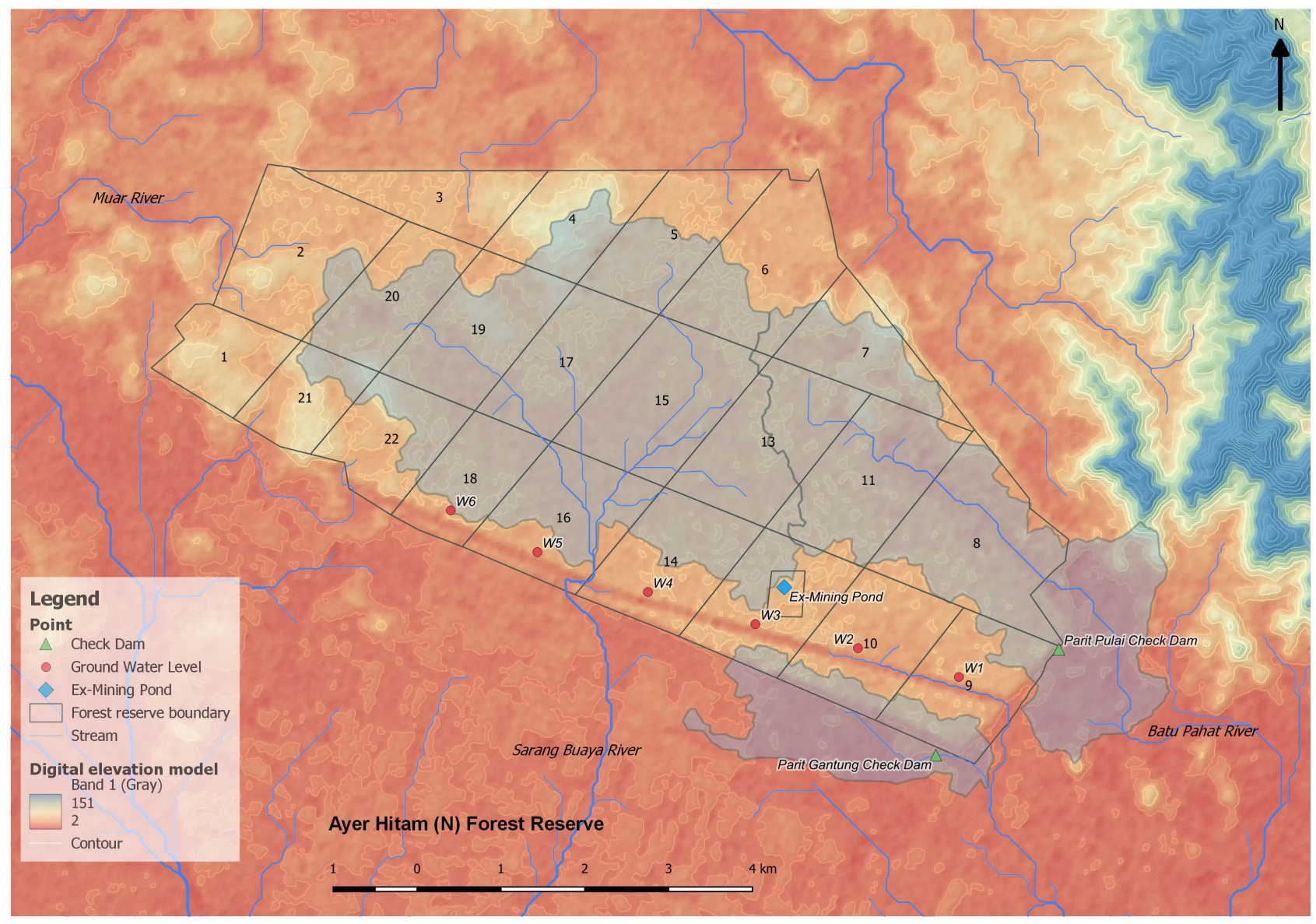

Figure 1. Satellite imagery shows the 3-D topographic view of AHNFR as well as the hilly areas in the western, northern, and northeastern parts of the reserve. 


\subsection{Vegetation of the AHNFR}

Based on a 2015 vegetation survey in the AHNFR [13], in the PSF-which is defined by the presence of organic soils-there are 69 species and 30 families of plants. The five most abundant species found were Syzygium cerinum var. cerinum (called Kelat, from family Myrtaceae), Syzygium inophyllum var. bernaddi (Kelat), Palaquium hexandrum (Nyatoh jambak), Santiria rubiginosa (Kedondong), and Stemonurus secundiflorus (Sampul keris). The vulnerable species Gonystylus bancanus (Ramin melawis) and the endangered species Shorea platycarpa (Meranti paya) were also identified.

The presence of mineral soil and a slightly higher elevation than the PSF characterized the lowland forest (Figure 2). Additionally, the low water table did not influence the lowland forest floor, as is peat swamp forest. Seventy-three species and 33 families of plants were found. The five most abundant were Syzygium inophyllum (Kelat) followed by Macarangga lowii (Mahang hutan), Aglaia palembanica (Bekak), Dipterocarpus crinitus (Keruing mempelas), and Aidia densiflora (Menterbang). The number of species recorded in the lowland forest is slightly higher than that in the PSF.

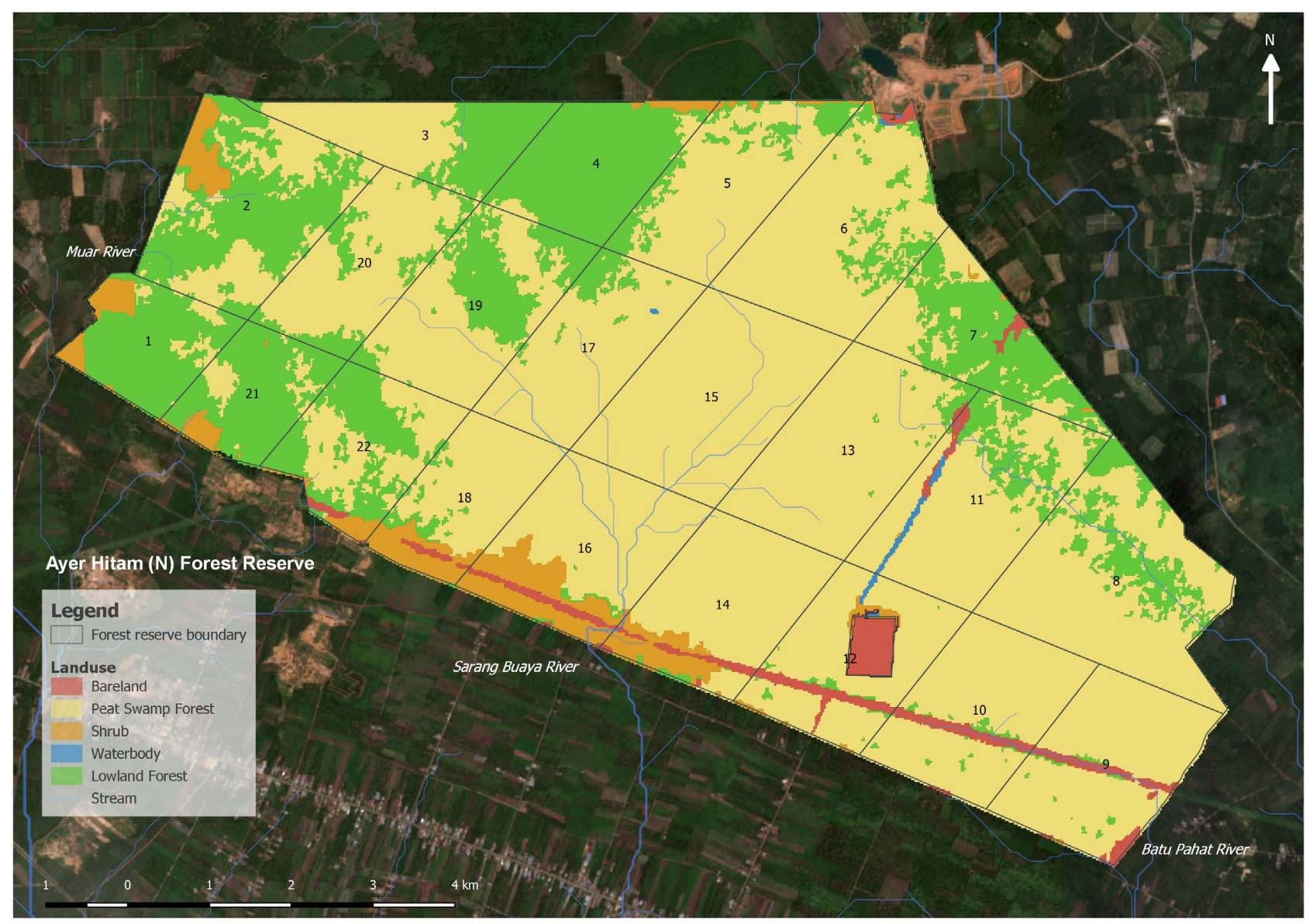

Figure 2. Satellite imagery shows the two types of forests in the AHNFR. The bright green color indicates lowland forest, and the dull green color indicates peat swamp forest. 


\subsection{Soil Characteristics of the AHNFR}

PSF develops on waterlogged sites after the formation of the peat layer from organic matter. The decomposition occurs under anaerobic conditions, which retard microbial degradation; because the partly decomposed organic matter builds up to form a layer of peat over the clay soil. It takes many years for substantial levels of peat to form, with estimated deposits of only $2.5-4.5 \mathrm{~mm}$ per year [14].

The 2017 soil survey in AHNFR [15], determined that the parent material is organic deposits over sulfuric marine clay. The soil pit at the edge of AHNFR extending $1.5 \mathrm{~m}$ below the soil surface revealed that the dominant material in the subsurface layer was sapric, with undecomposed wood (Table 1). The actual depth in this area is 8 metres; peat thicker than 3 metres falls into the classification called the Teraja series. Overall, peat levels up to 9 metres can be found (Figure 3). The normal concave shape of the peat depth is defined because the peatland areas extend outside the forest reserve.

Table 1. Cross-section of peat depth from the hilly areas to the boundary of AHNFR near the TNB power line tower.

\begin{tabular}{ccl}
\hline Horizon & Depth $(\mathrm{cm})$ & \multicolumn{1}{c}{ Description } \\
\hline $\mathrm{Oa}_{1}$ & $0-50$ & $\begin{array}{l}\text { Black (10YR2/1) highly decomposed sapric organic material; } \\
\text { fine granules; dry loose; clear smooth boundary. }\end{array}$ \\
& $50-75$ & $\begin{array}{l}\text { Very dark brown (10YR3/3) highly decomposed sapric organic } \\
\text { soil material with many large undecomposed wood pieces; wavy } \\
\text { boundary. }\end{array}$ \\
Oawd $_{1}$ & $\begin{array}{l}\text { Very dark brown (10YR3/3) highly decomposed sapric organic } \\
\text { soil material; wet, massive, and sticky; many large } \\
\text { undecomposed pieces of wood. }\end{array}$ \\
Oawd $_{2}$ & $75-110$
\end{tabular}

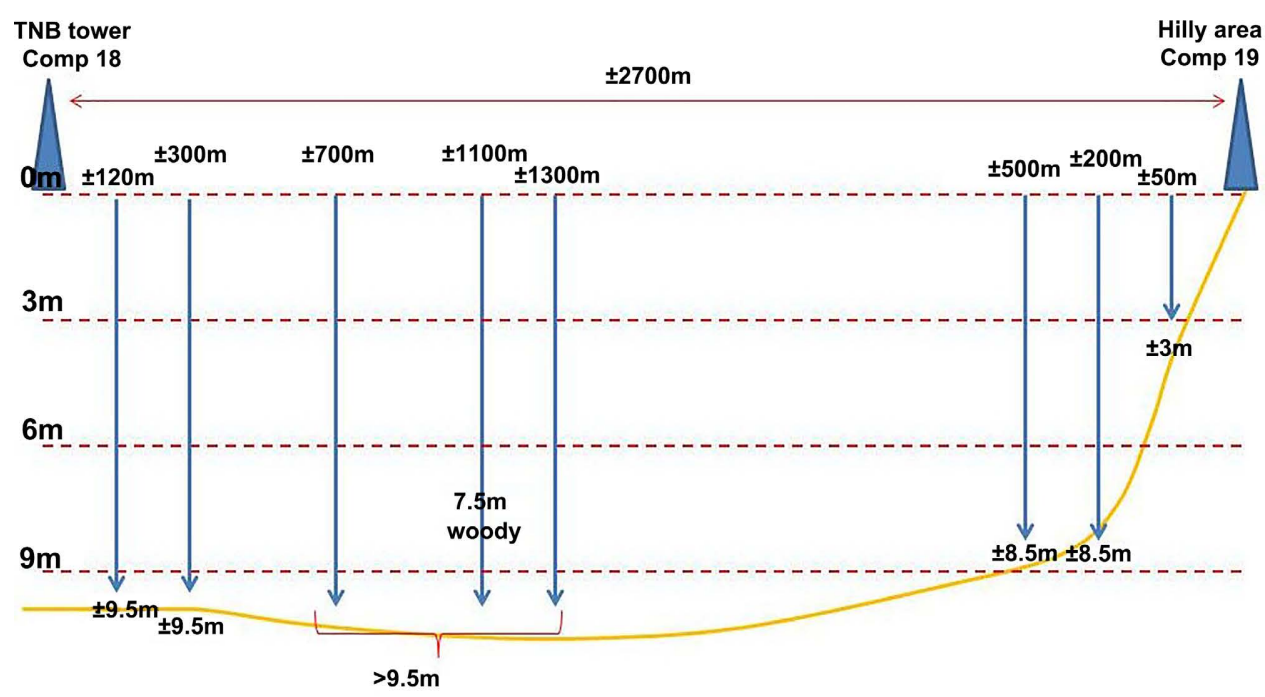

Figure 3. Cross-section of peat depth from the hilly area to the boundary of AHNFR near the TNB power line tower. 


\subsection{Water Quality Status before and after the Establishment of Check Dams}

Five physico-chemical water quality parameters were observed at the study sites before and after the dam was constructed. Compared to water quality of freshwater rivers in lowland forest the black water found is acidic ( $\mathrm{pH} 3.04)$, with low total dissolved solids (TDS) and dissolved oxygen (DO), but greater conductivity. Table 2 shows the water quality parameters before and after the check dam was installed. Aluminium (Al) concentration was reduced, which produces better conditions for the oil palm trees. DO value increased, improving the water quality, and conductivity and TDS also increased. The $\mathrm{pH}$ values are still acidic.

\subsection{The Drainage System in the AHNFR}

The AHNFR is developed between three river systems that are the Muar River, whose upper catchment originates in the northwestern parts of the hilly areas, while the Batu Pahat River and Sarang Buaya River are in the southeast and southern areas. The Sarang Buaya flows into the Straits of Malacca. The upper catchment of the Sarang Buaya River is delineated by GIS and literally the distinct drainages were not found at the location. The slope of the peat swamp land surface is considered gentle, except for some higher ground primarily located in the western areas, where the maximum height is $40 \mathrm{~m}$. Small highland freshwater streams extend into the edges of the eastern parts of the forest area. Field observations show that surface water flows in a south western direction in small canals. These canals were constructed mainly for water management in an oil palm plantation and other agricultural activities surrounding the AHNFR. Apart from that, some side ditches constructed along the Tenaga National Berhad (TNB) power line access road fall within the forest reserve area.

\section{Materials and Methods}

\subsection{Rainfall Observation}

In January 2016, a rainfall station was set up at Kompleks Penghulu (KP), Mukim Ayer Hitam using a SEBA Hydrometrie RG60 gauge with a tipping bucket

Table 2. Differing water quality values before and after the establishment of the check dam at Parit Pulai.

\begin{tabular}{ccc}
\hline Parameter & $\begin{array}{c}\text { Without check dam } \\
\text { (October 2016) }\end{array}$ & $\begin{array}{c}\text { After check dam constructed } \\
\text { (January 2017) }\end{array}$ \\
\hline DO & $1.12 \mathrm{mg} / \mathrm{L}$ & $4.99 \mathrm{mg} / \mathrm{L}$ \\
$\mathrm{Al}$ & $0.31-0.57$ & $0.19-0.20 \mathrm{ppm}$ \\
Conductivity & $110 \mu \mathrm{S} / \mathrm{cm}$ & $145 \mu \mathrm{S} / \mathrm{cm}$ \\
TDS & $69 \mathrm{mg} / \mathrm{L}$ & $92 \mathrm{mg} / \mathrm{L}$ \\
pH & 3.04 & 2.93 \\
Temperature & $27^{\circ} \mathrm{C}$ & $26.7^{\circ} \mathrm{C}$ \\
\hline
\end{tabular}


of $1.0 \mathrm{~mm} /$ tip that was connected to HB event logger (SFS89424). Additionally, a conventional rainfall recorder was also set up for back-up.

\subsection{Groundwater Level Monitoring}

There were six points for the groundwater level (GWL) monitoring as shown in Figure 1. In June 2015, two piezometers equipped with Van Essen Cera-Diver well data logger sensors were set up for continuously measuring and recording the groundwater levels in Compartments 10 (W2) and 14 (W4). In May 2016, another Cera-Diver was installed in Compartment 18 (W6). This device measures the pressure (piezometric head) of groundwater. The data were recorded in 30-minute intervals. Water levels were also directly measured manually from PVC tube wells in Compartments 9 (W1), 12 (W3), 16 (W5). Compartments 1, 21 , and 22 were excluded from the monitoring because the land surfaces were covered with mineral soils. The barometer was also set up to measure the atmospheric pressure at $\mathrm{W} 2$.

Groundwater levels were monitored to determine the changes corresponding to the monsoon and to check if there are any differences in groundwater levels along the forest boundaries that correlate with the gradient in that area.

\subsection{Check Dam Construction for Hydrological Conservation at PSF}

A survey was conducted to identify the locations of peat drainage outflow near the border of the forest reserve. The establishment of oil palm plantations requires a drainage system needs before planting activities. The networking of drainage system established along the border of the forest reserve describes the major drainage system. From the forest reserve border, points 1 and 3 only $40 \mathrm{~m}$ and $60 \mathrm{~m}$, respectively. The check dams, a simple design made from concrete, were constructed at points 1 and 3 because they are the nearest to the forest border. Van Essen Cera-Diver water level sensor measured continuously in the drain at both locations before and after the construction of the check dams. The check dam at point 1 was installed in December 2016, and one at point 3 in 2017. These dams block the flow of water out of the forest, thus maintaining the groundwater level in the forest while also serving as part of the water management system in the oil palm plantation.

\section{Results}

\subsection{Rainfall}

Total rainfall monitored by RG60 from March to December 2016 was $1941 \mathrm{~mm}$ (Figure 4). Data for January 28 to March 7 were not available due to technical error. The amount of rain collected using the conventional method for this lost period was $277.5 \mathrm{~mm}$. Combining these two measurements, the total amount of rainfall observed in 2016 was $2218.5 \mathrm{~mm}$. In 2017, total rainfall was $2436 \mathrm{~mm}$. There were no extreme monthly quantities of rainfall recorded during this period. 


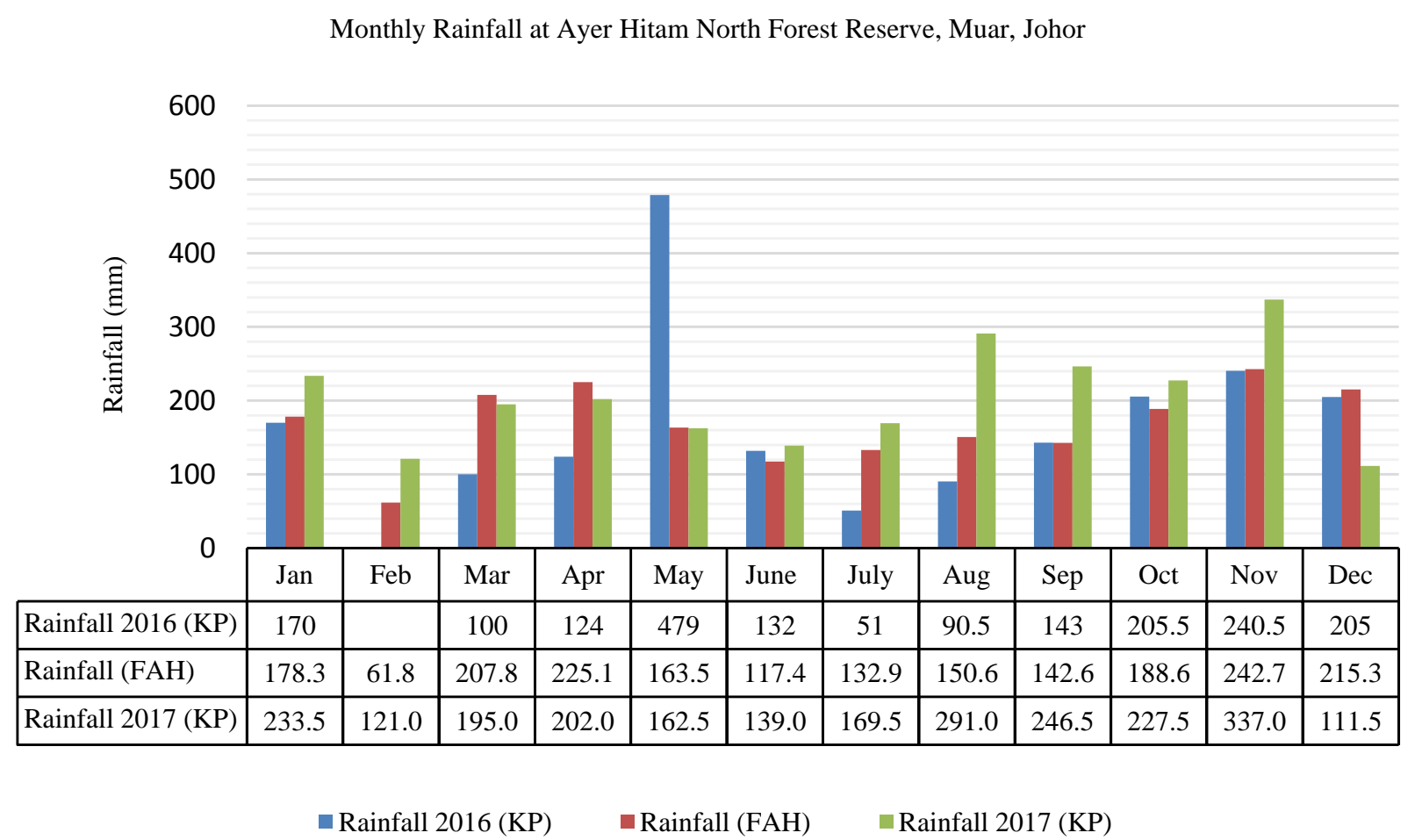

Figure 4. Monthly rainfall in the years 2016 and 2017 observed at the Kompleks Penghulu (KP) station Ayer Hitam, compared to 16-year monthly average rainfall at Felda Ayer Hitam (FAH).

A comparison of the monthly rainfall at KP station and the Malaysian Meteorological Department's (MMD) data on 16 years (2000-2015) of monthly average rainfall at Felda Ayer Hitam (FAH) station shows a similar pattern. In this bimodal pattern, November and April had the highest points, while February and July had the lowest points. However, in May 2016, 479-mm rain was recorded at KP station, which is high compared with the monthly average at the FAH station. The average annual rainfall at FAH is $2027 \mathrm{~mm}$.

\subsection{Groundwater Level}

Observations by piezometers at W2, W4, and W6 show that the monthly average GWL at the three locations demonstrated the same fluctuation, but with different rates, which indicated their response to rainfall events. Less rainfall was observed from May to September during the southeast monsoon and it was found that the GWL at W4 dropped to the lowest at $90 \mathrm{~cm}$ below the surface. Groundwater levels were closed at the soil surface during the wet season from December to February the following year. GWLs at W2, W4, and W6 from January to December 2016 indicated that the groundwater level at W2 was closer to the surface compared to W4 and W6 (Figure 5). The GWL at W2 ranged from $0-46.9 \mathrm{~cm}$ below the surface; the GWLs at W6 and W4 ranged from $1.6-64.1 \mathrm{~cm}$ and 2 $90.6 \mathrm{~cm}$ below the surface, respectively. The different groundwater levels at the three locations showed that the slope of the ground surface is higher toward the north and west of the forest reserve than at the southeast. 

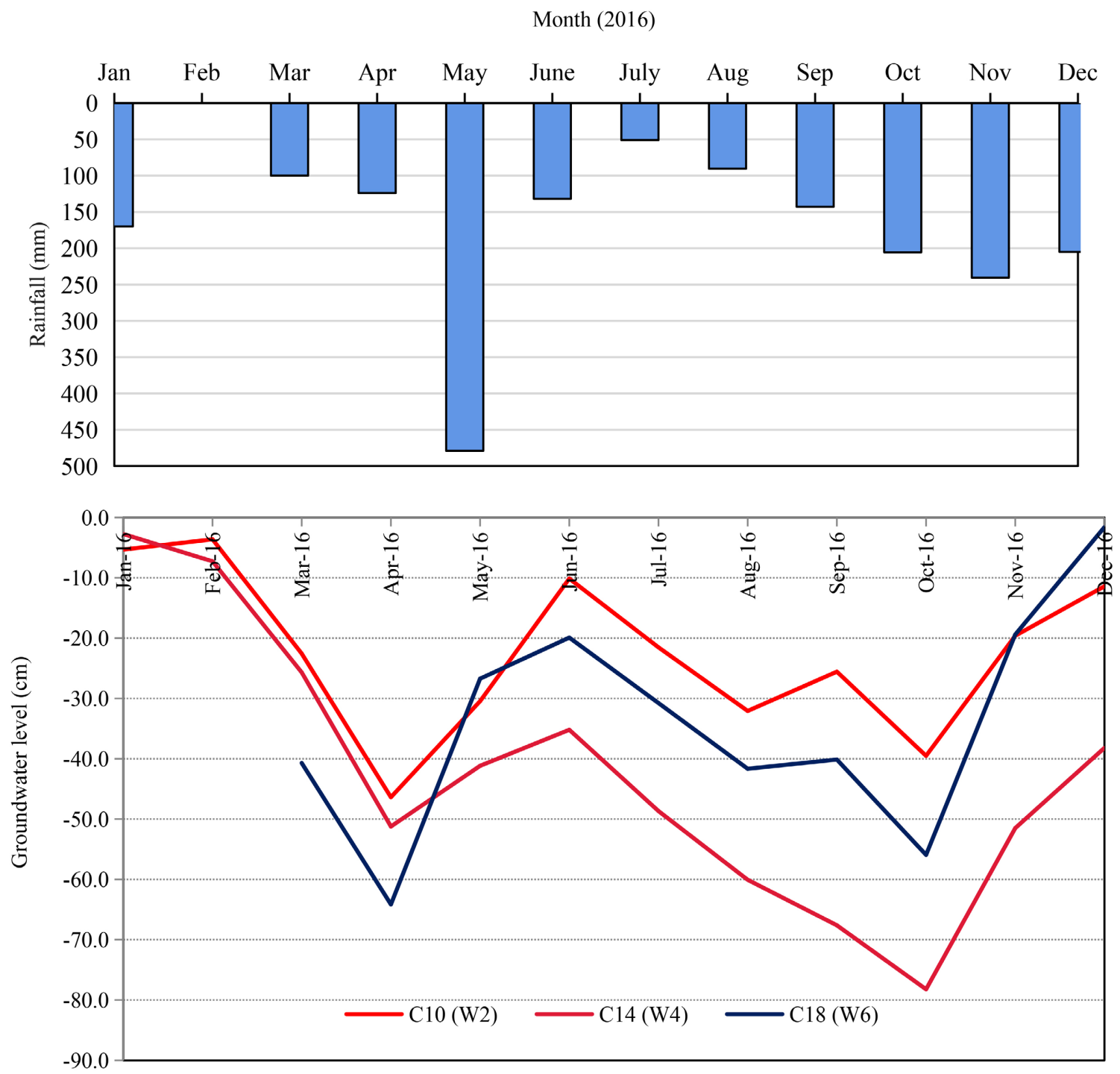

Figure 5. Monthly rainfall (top graph) and a comparison with groundwater levels (bottom graph) from January to December 2016 at AHNFR.

The GWLs were almost at the surface in December 2015, and January and February 2016 (the period of the NE monsoon). The GWL also increased in June 2016 following a large amount of rainfall in May 2016, which indicates that the GWL in the forest reserve remains at the same level for up to 30 days. The lowest points occurred in April and October 2016. The ground surface at W2 was wetter than that at other locations, but the results also show that the GWL at W6 was sometimes higher than at W2 and W4. The lower ground surface at this site as evidence of headwater catchment delineated from the satellite imaginary map in Compt. 18. From January to June 2017 the GWL at W4 remains the lowest compared to W2 and W6.

A correlation between GWL and rainfall has occurred. The GWL decreases with less rainfall; a large amount of rainfall in a particular month results in a slow but continuous rise of the GWL toward the surface. In this situation, the 
maximum water level will be detected the following month as shown in May 2016 that after heavy rain received this month and the GWL reached its maximum in June 2016.

In 2017, the GWL at W2 and W6 was close to the surface from January to April. In May, the GWL at W6 was $17 \mathrm{~cm}$ above the surface. At C10 and C18 levels were above the surface from May to December (Figure 6). The water level differs from 2016, in which the GWL was below the surface at all three locations.

Monthly GWLs were observed manually at points W1, W2, W3, W4, W5, and W6. Figure 7 and Figure 8 show the same fluctuations measured by the automatic sensors. The GWLs at W1 and W2 were closer to the surface compared to the other points. The lowest water level was in October, while the highest was in December. In 2016, the highest values ranged from $4-34.8 \mathrm{~cm}$, and the lowest from $41.5-81.5 \mathrm{~mm}$. In 2017, GWLs ranged from $1.2-49.2 \mathrm{~cm}$ and were above the surface in May at W5 and W6.
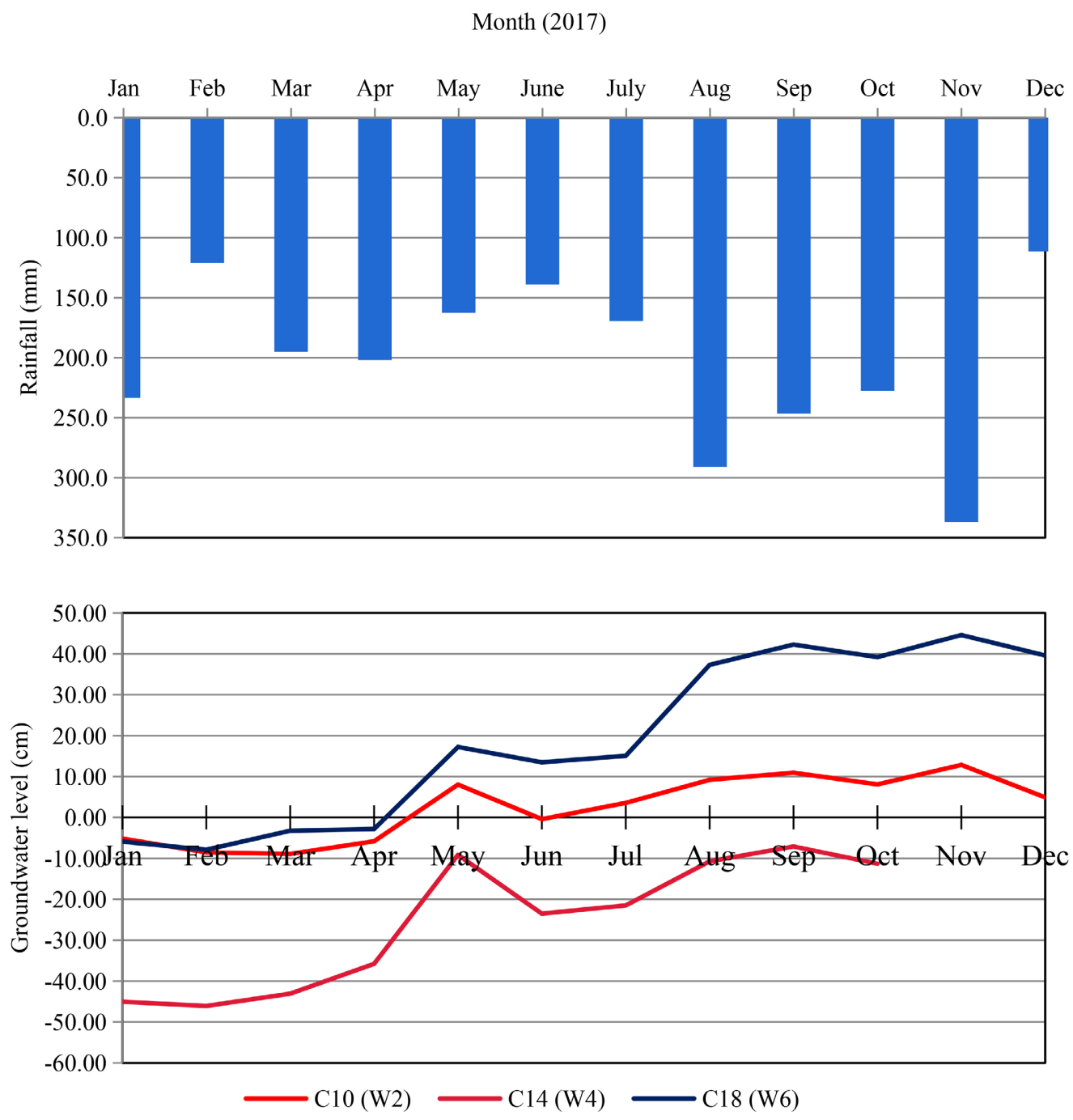

Figure 6. Monthly rainfall (top graph) and a comparison with groundwater levels (bottom graph) from January to December 2017 at AHNFR. 


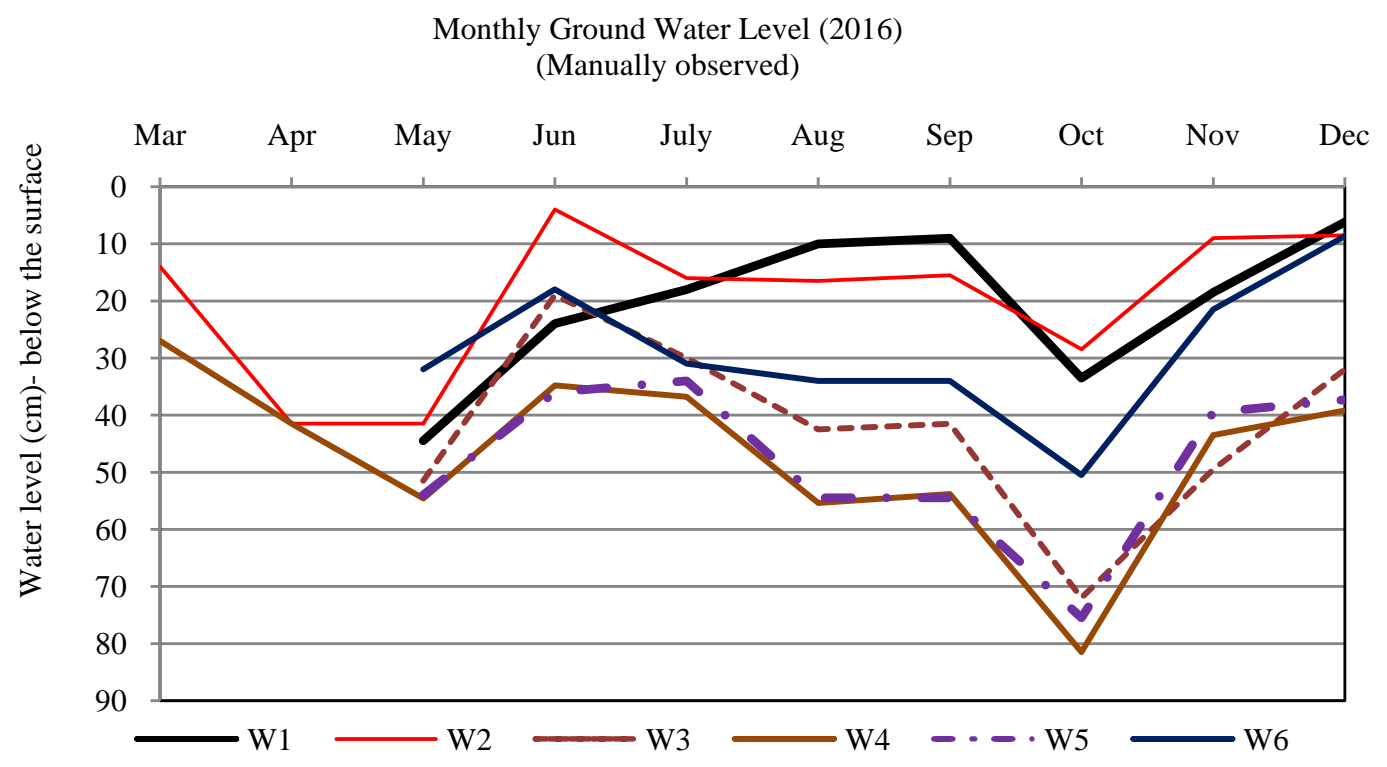

Figure 7. Fluctuation of monthly groundwater levels manually measured from the PVC tube wells from March to December 2016.

Monthly Ground Water Level (2017)

(Manually observed)

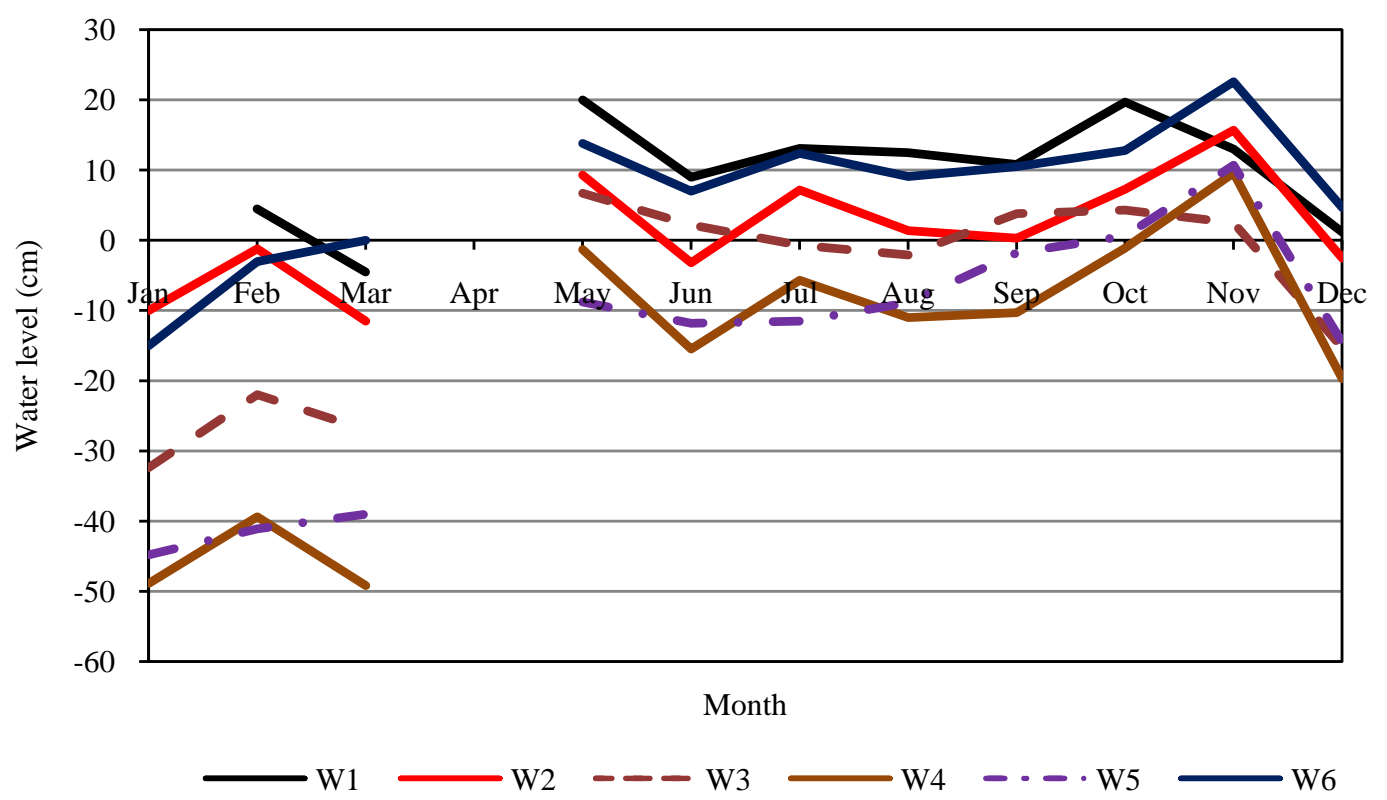

Figure 8. Fluctuation of monthly groundwater levels manually measured from the PVC tube wells from January to December 2017.

\section{Check Dams as a Hydrological Conservation Measure of PSF}

\subsection{Discharge and Water Level Changes at Parit Pulai (Point 1)}

The check dam used has a rectangular outlet, which is effective for use at a shallow drain. It blocks water flow until the maximum level is reached, then the water breaches the top edge of the outlet (Figure 9). 


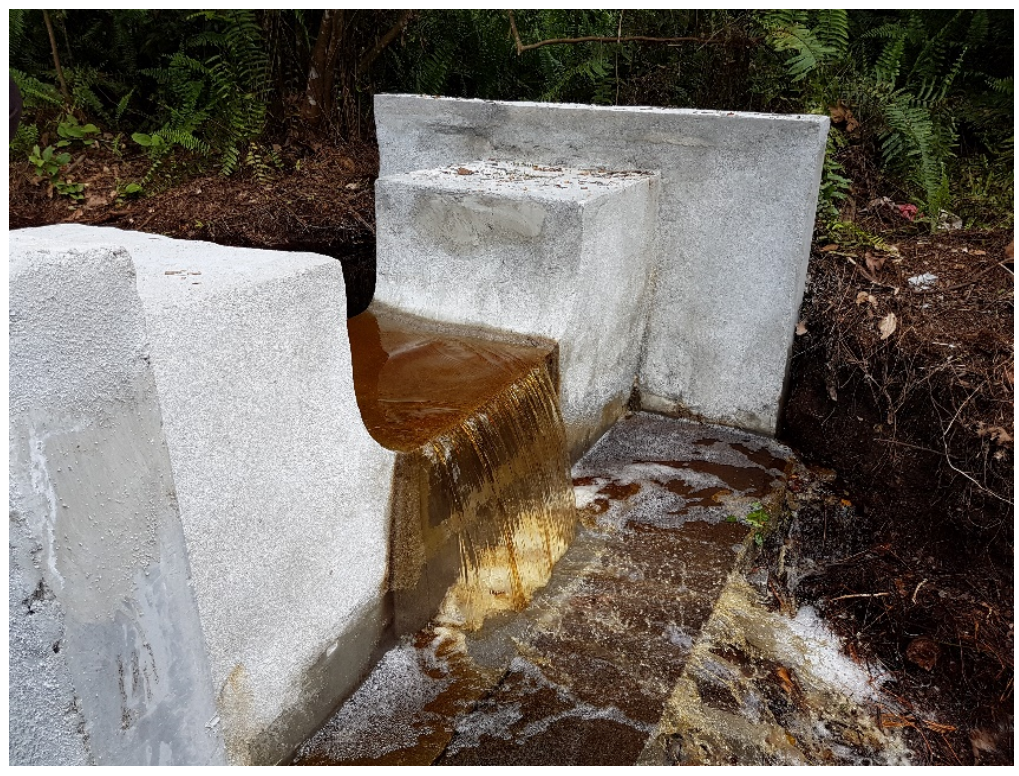

Figure 9. The design of check dam established at Parit Pulai and Parit Gantung.

\subsubsection{Flow Rate from the Drain before Construction of the Check Dams}

The flow rate or discharge from the drain at Parit Pulai was calculated by determining the cross-sectional area and flow velocity. The calculation of discharge $(Q)$ as shown in Equation (1).

$$
\begin{aligned}
Q & =A \times V \\
& =0.13 \mathrm{~m}^{2} \times 0.201 \mathrm{~m} \cdot \mathrm{s}^{-1} \\
& =0.0261 \mathrm{~m}^{3} \cdot \mathrm{s}^{-1}
\end{aligned}
$$

Hence, $Q$ is the discharge $\left(\mathrm{m}^{3} \cdot \mathrm{s}^{-1}\right), A$ is the cross-sectional area $\left(\mathrm{m}^{2}\right)$ and $V$ is the velocity $\left(\mathrm{m} \cdot \mathrm{s}^{-1}\right)$.

The value of $Q$ is based on baseflow conditions. The maximum depth of the water was $26.0 \mathrm{~cm}$, and the minimum depth was $0.5 \mathrm{~cm}$. In terms of yearly estimation, the volume obtained is $823,089 \mathrm{~m}^{3}$.

\subsubsection{Water Levels in the Drain before and after Check Dam Construction at Parit Pulai}

In September 2016, before the installation of the check dam, a water level sensor was installed at Point 1 to measure the surface water level in the drain at 30-minute intervals. Water level monitoring continued after the check dam was implemented in December 2016. The water levels after the dam installation raised from $8.0 \mathrm{~cm}$ in September 2016 to $33.2 \mathrm{~cm}$ in January 2017 (Figure 10). The water levels which were obtained between $20.1-25.5 \mathrm{~cm}$ from September to November 2017 showed that the groundwater level has been conserved compared with the same periods in 2016.

The water levels increased from September to November 2016 due to rainfall amounts during those months in that area. The maximum held water level of the check dam is $55 \mathrm{~cm}$, so it will overflow to both sides of the structure when heavy rain occurs in the monsoon. Observed waterlevels increased to $33.2 \mathrm{~cm}$ in 
The water level changes with rainfall at Parit Pulai

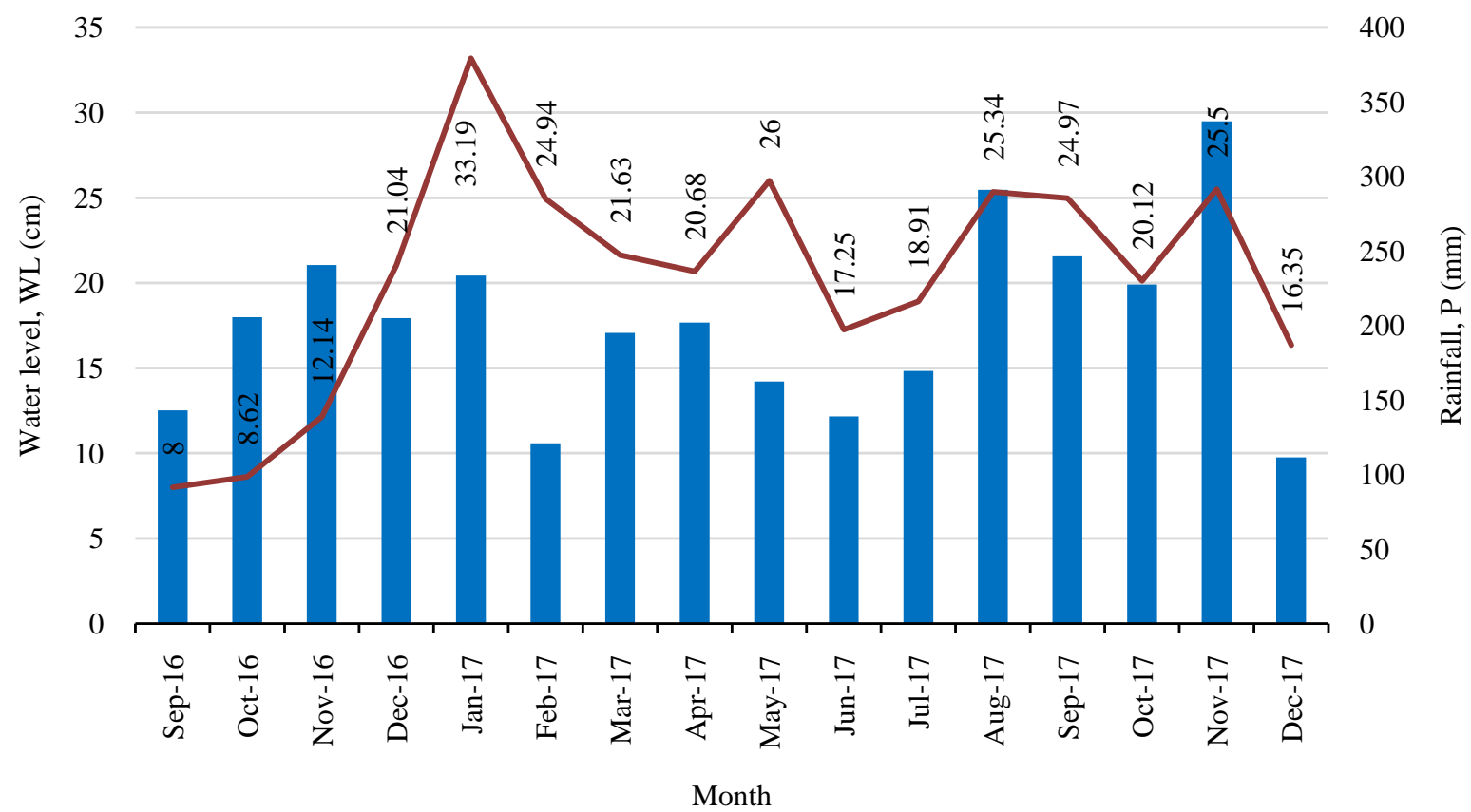

$\mathrm{P}(\mathrm{mm}) \quad \mathrm{WL}(\mathrm{cm})$

Figure 10. Monthly water level recorded in the drain before and after the check dam was constructed at Parit Pulai.

January 2017, and the level fluctuates from February to May 2017. The water level decreased in June 2017 as the dry season approached. The 2017 data show an average water level of $22.9 \mathrm{~cm}$, while the average before the dam was constructed-from September to December 2016-was $9.58 \mathrm{~cm}$; in other words, the average water level increased at least $13.31 \mathrm{~cm}$ with the implementation of the check dams.

\subsubsection{Discharge from the Check Dams}

The calculation of the amount of discharge from the check dam is based on the Kindsvater-Carter rectangular weir equation [16] [17] for partially contracted weirs as shown in Equation (2). The check dam specification as shown in Figure 11.

$$
Q=C_{e} \frac{2}{3} \sqrt{2 g}\left(b+K_{b}\right)\left(h+K_{h}\right)^{3 / 2}
$$

where,

$$
\begin{aligned}
& Q=\text { Discharge }\left(\mathrm{L}^{3} / \mathrm{T}\right) \\
& C_{e}=\text { Discharge Coefficient } \\
& g=\text { Acceleration of gravity }\left(9.8066 \mathrm{~m} \cdot \mathrm{s}^{-1}\right) \\
& b=\text { Notch width }(\mathrm{L}) \\
& h=\text { Head }(\mathrm{L}) \\
& K_{b} \& K_{h} \text { account for effective viscosity \& surface tension }(\mathrm{L}) \\
& K_{h}=\text { effective head }(0.001 \mathrm{~m})
\end{aligned}
$$




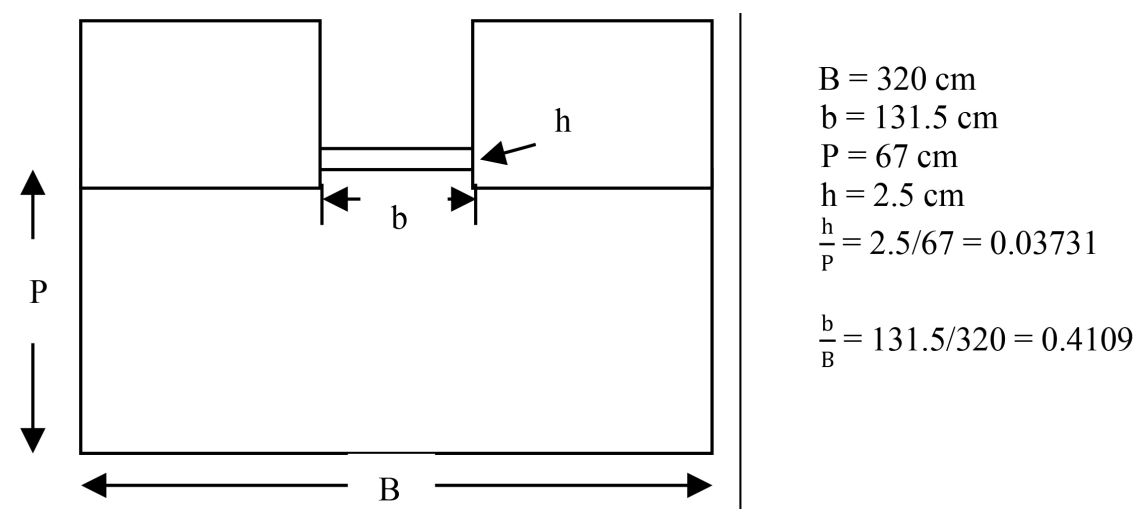

Figure 11. The check dam dimension at Parit Pulai.

$$
\begin{aligned}
K_{b} & =\text { effective width } \\
C_{e} & =0.59 \\
K_{b} & =2.4 \mathrm{~mm}=0.24 \mathrm{~cm}
\end{aligned}
$$

Hence,

$$
\begin{aligned}
Q & =0.59 \times 0.667 \times \sqrt{19.61} \mathrm{~m} \cdot \mathrm{s}^{-1}(1.315 \mathrm{~m}+0.0024 \mathrm{~m})(0.025 \mathrm{~m}+0.001 \mathrm{~m})^{3 / 2} \\
& =0.394 \times 4.428 \times 1.317 \times 0.00433 \mathrm{~m}^{3} \cdot \mathrm{s}^{-1} \\
& =0.00956 \mathrm{~m}^{3} \cdot \mathrm{s}^{-1}
\end{aligned}
$$

The direct calibration of flow rate at the check dam's outlet is $0.00675 \mathrm{~m}^{3} \cdot \mathrm{s}^{-1}$. The flow rate decreased from $0.026 \mathrm{~m}^{3} \cdot \mathrm{s}^{-1}$ to $0.00956 \mathrm{~m}^{3} \cdot \mathrm{s}^{-1}$ after the check dam was constructed.

Based on Batu Pahat River head water catchment of 918 hectares, the yearly estimation of water replenished, with net increment of water level $133 \mathrm{~mm}$ as in Equation (3).

$$
V=\frac{W L \times A}{1000}
$$

where, $V$ is the water volume $\left(\mathrm{m}^{3}\right), W L$ is the water level $(\mathrm{mm})$ and $A$ is the catchment area $\left(\mathrm{m}^{2}\right)$.

Hence,

$$
\begin{aligned}
V & =\frac{133 \times 918 \times 10000}{1000} \\
& =1221858 \mathrm{~m}^{3}
\end{aligned}
$$

The result shows that 1.221 million $\mathrm{m}^{3}$ of water was conserved from leaving the forest reserve with the implementation of the check dam at Parit Pulai.

\section{Discharge and Water Level Changes at Parit Gantung}

\subsection{Flow Rate from the Drain before Check Dam Construction}

At Parit Gantung, which is Point 3, the water level was continuously monitored from December 2016 through the completion of the check dam in March 2017, to the end of 2017 (Figure 12). Additionally, the profile of the drain was measured for calculating the flow rate. 
The water level with rainfall at Parit Gantung (2017)

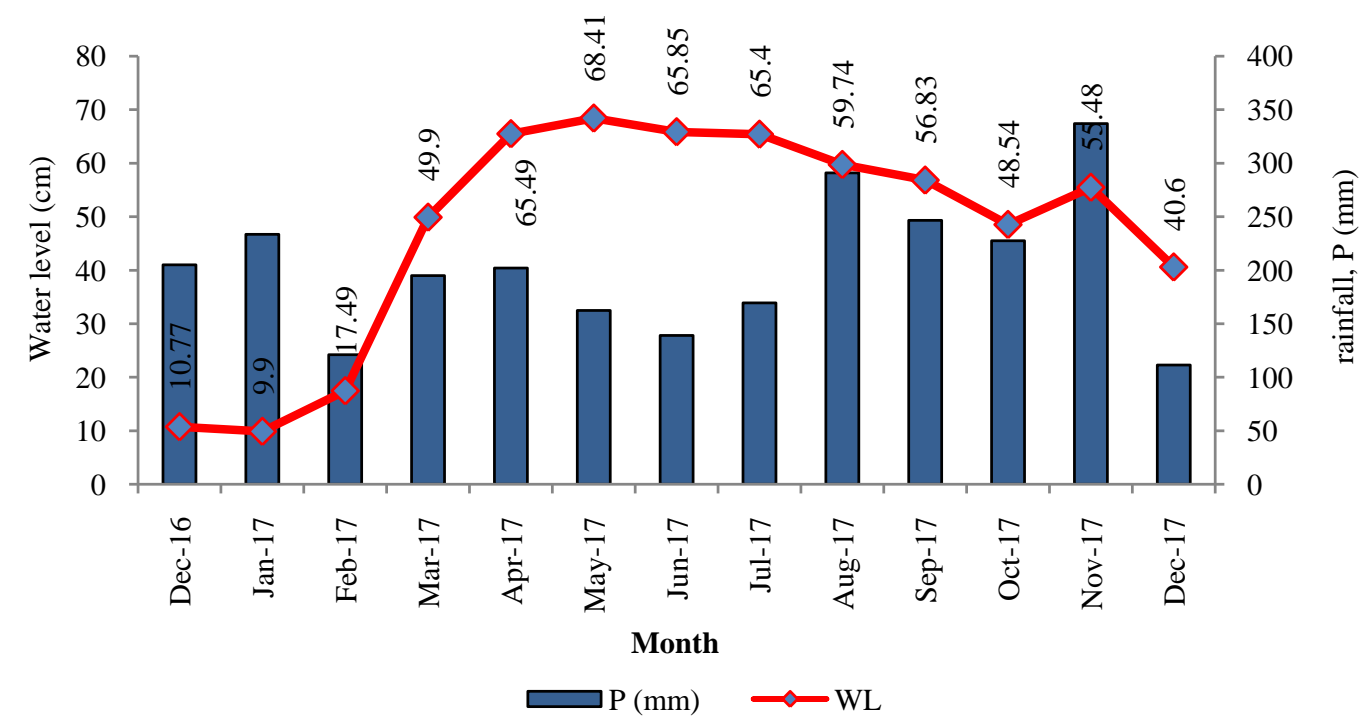

Figure 12. Monthly water levels recorded in the drain before and after the check dam was constructed at Parit Gantung.

\subsection{Water Level before and after Check Dam Construction at Parit Gantung}

As expected, water levels increased in April 2017 after the completion of the dam. Observed water levels increased from $17.5 \mathrm{~cm}$ in February to $65.5 \mathrm{~cm}$ in April 2017 and remained above $60 \mathrm{~cm}$ in May and June 2017. The changes in the surface water level were ranged from $10.8 \mathrm{~mm}$ to $68.4 \mathrm{~mm}$. The greatest water level increased was $58.5 \mathrm{~cm}$.

The average before the dam was constructed from December 2016 to February 2020 was $12.7 \mathrm{~cm}$ and the average water level of $57.6 \mathrm{~cm}$ after the establishment of the check dam from Mac to December 2020. Hence, the average water level increased was $44.9 \mathrm{~cm}$. The lower WL was recorded in December because of water flow diversion by the plantation.

\subsection{Discharge before and after Check Dam Construction}

Flow rate measured from the drain before construction:

$$
\begin{aligned}
Q & =0.144 \mathrm{~m}^{2} \times 0.486 \mathrm{~m} \cdot \mathrm{s}^{-1} \\
& =0.0699 \mathrm{~m}^{3} \cdot \mathrm{s}^{-1}
\end{aligned}
$$

The yearly discharge estimated from the forest reserve is $2,204,366 \mathrm{~m}^{3}$.

Discharge from the check dam's outlet:

$$
\begin{aligned}
Q & =0.59 \times 0.667 \times \sqrt{19.6} \mathrm{~ms}^{-1}(0.93 \mathrm{~m}+0.0275 \mathrm{~m})(0.03 \mathrm{~m}+0.001 \mathrm{~m})^{3 / 2} \\
& =0.3935\left(4.428 \mathrm{~ms}^{-1}\right)(0.9575 \mathrm{~m})(0.005167 \mathrm{~m}) \\
& =0.008619 \mathrm{~m}^{3} \cdot \mathrm{s}^{-1}
\end{aligned}
$$

The flow rate decreased from $0.0699 \mathrm{~m}^{3} \cdot \mathrm{s}^{-1}$ before the construction of the check dam to $0.00862 \mathrm{~m}^{3} \cdot \mathrm{s}^{-1}$ afterward. The directly calibrated flow rate at the check 
dam's outlet is $0.00667 \mathrm{~m}^{3} \cdot \mathrm{s}^{-1}$, which is not much different from the outlet of the check dams.

Based on Sarang Buaya River head water catchment of 267.4 hectares, the yearly estimation of water replenished with net increment of water level of 449 mm below:

$$
\begin{aligned}
V & =\frac{449 \times 267.4 \times 10,000}{1000} \\
& =1200626 \mathrm{~m}^{3}
\end{aligned}
$$

The result shows that 1.201 million $\mathrm{m}^{3}$ of water was conserved from leaving the forest reserve with the implementation of check dam at Parit Gantung.

Besides the Coronavirus 2019 (COVID-19) pandemic, only check dam at Parit Pulai maintenance manage to conduct at the end of 2019 and the measurement continued in 2020. The observation shows that the ground water level increment was higher after redesigning of the check dam from rectangular to V-notch shape. Indirectly, it also means that more water has been retained in the forest reserve. Based on net water level increment of $18.4 \mathrm{~cm}, 1,689,120 \mathrm{~m}^{3}$ of water was replenished with reference to head water catchment of Batu Pahat River in 2020. In terms of flow rate, it was reduced from $0.252 \mathrm{~m}^{3} \cdot \mathrm{sec}^{-1}$ to $0.1057 \mathrm{~m}^{3} \cdot \mathrm{sec}^{-1}$.

\section{Discussion}

Ayer Hitam North Forest Reserve (AHNFR) plays important roles in hydrological functioning of the entire Air Hitam peatland. It plays a vital role in regulating flow and storing water. With its capability to absorb large amounts of water, peat swamp forest function reduces the risk of flooding to the downstream areas. AHNFR is the last remaining peat swamp forest in Johor State as its surrounding land has been changed to other land uses and degraded by drainage. The reclamation history of the peatland area has occurred since 1970s-1980s, before conversion to oil palm plantations occurred in the 1980s.

The forestry department has taken a step to gazette the forest reserve as State Park Forest and prepare the management plan and action plan. These efforts will ensure the future of AHNFR through conservation and restoration efforts.

The establishment of the buffer zone also prevents the effect of subsidence in AHNFR. Reference [12] mentioned that, appending buffer zone prevents 1.8 metres land shrinks along its periphery in the next 90 years with estimation of $0.8 \mathrm{~cm} /$ year.

The project methodology has limitations. The water levels measured in the drains should be covered at least a year before the dam installation to get a better yearly average. The water level changes followed the rainfall seasons.

Regular maintenance of the check dam is necessary as the sediment trapped behind the structure affects water level recordings. During periods of less rainfall-such as March and April—the low water level and accumulation of sediment prevents water from flowing through the check dam's outlet. The sedimentation occurred at Parit Gantung because the check dam is located in the 
plantation area. The check dam maintenance process occurred again in late 2019 , and monitoring of the changes in water level in the drain and the discharge from the check dam's outlets continues. The direct calibration from the dam outlets during monsoon has difficulties conducting as the water flows were heavy after rainfall events. The monsoon also limits the fieldtrip with the occurrence of flood in the southern part of the country.

\section{Conclusion}

This study confirms that the drainage system affected the GWL in the peat swamp forest. The check dams helped increase and maintain the PSF groundwater levels and thus reduce the risk of forest fires during the dry season. They also reduce the outflow from the PSF and improve water quality by creating flow instability after falling from the outlet, which has a positive impact on the growth of oil palm trees. The output from this project assists the Coca-Cola (Malaysia) Company to achieve its target in water conservation and restoration by water replenishing back into the environment with volume as much as 1.2 million $\mathrm{m}^{3}$ year $^{-1}$. In conclusion, this project can be maintained as it has the benefits to conserve groundwater level in the forest reserve and hence, the preservation of AHNFR.

\section{Acknowledgements}

The authors want to thank the Yayasan Kemanusiaan Muslim Aid Malaysia and the Coca-Cola Company (Malaysia) for providing funding through Grant No. 51310702003.

\section{Conflicts of Interest}

The authors declare no conflicts of interest regarding the publication of this paper.

\section{References}

[1] Wetlands International (2010) Wetlands International-Malaysia. A Quick Scan of Peatlands in Malaysia.

[2] Miettinen, J., Shi, C. and Liew, S.C. (2011) 2 Decades of Destruction in Southeast Asia's Peat Swamp Forests. Frontiers in Ecology and the Environment, 10, 124-128. https://doi.org/10.1890/100236

[3] Forestry Department Peninsular Malaysia (2019) Peninsular Malaysia Forestry statistics 2019. http://www.forestry.gov.my

[4] Appanah, S., Ismail, H., Samsudin, M. and Sadali, S. (1999) Flora Survey in North Selangor Peat Swamp Forest. In: Chin, T.Y. and Havmoller, P., Eds., Sustainable Management of Peat Swamp Forest in Malaysia, Vol. 1: Resource and Environment. Forestry Department, Malaysia.

[5] State Forestry Department, Malaysia (2016) Rancangan Pengurusan Hidrologi Hutan Paya Gambut Selangor Utara (HPGSU), Selangor 2016-2026. Forestry Department, Malaysia. 
[6] Anderson, J.A.R. (1963) The Flora of the Peat Swamp Forest of Sarawak and Brunei, Including a Catalogue of all Recorded Species of Flowering Plants, Ferns and Fern Allies. Gardens Bulletin, 20, 131-228.

[7] Pahang Forestry Department, Malaysia (2004) Hydrological Assessment of the Pekan Forest Reserve, Pahang, Malaysia. Technical Report for Management for Conservation and Sustainable Use of Peat swamp Forest and Associated Water Regimes in Malaysia.

[8] Chan, H.T. (1989) A Forestry Action Plan for the North Selangor Peat Swamp Forest. Asian Wetland Bureau, Universiti Malaya WWF Malaysia. Asian Wetland Bureau, Kuala Lumpur Report Number 46c.

[9] Zulkifli, Y., Villy, K. and Baharuddin, K. (1999) Hydrological Characteristics of the North Selangor Peat Swamp Forest. Project Document Number 15, Malaysian-DANCED Project on Sustainable Management of Peat Swamp Forest.

[10] Wösten, J.H.M., Clymans, E, Page, S.E., Rieley, J.O. and Limin, S.H. (2008) Peat-Water Interrelationships in a Tropical Peatland Ecosystem in Southeast Asia. Catena, 73, 212-224. https://doi.org/10.1016/j.catena.2007.07.010

[11] Wösten, J.H.M, Ismail, A.B. and Van Wijk, A.L.M. (1997) Peat Subsidence and Its Practical Implication: A Case Study in Malaysia. Geoderma, 78, 25-36. https://doi.org/10.1016/S0016-7061(97)00013-X

[12] Dipa Satriadi, R. (2011) Drainage-Driven Subsidence and Carbon Emissions in Ayer Hitam Forest Reserve and Its Surrounding Area, Johor-Malaysia. Assessment Report for the Integrated Peatland Restoration Management and Action Plan of the Ayer Hitam Forest Reserve. Wetlands International Malaysia-Malaysia Office, Petaling Jaya, Selangor, Malaysia.

[13] Muslim Aid Malaysia (2015) Report on Water for Life Project 2014/2015 at Peat Swamp Forest, Ayer Hitam Forest Reserve (N), Johor. Muslim Aid Malaysia, Kuala Lumpur.

[14] Wetlands International Malaysia-Malaysia Office (2003) Peat Swamps Forests: Malaysia's Diminishing Forest Type. Wetlands International Malaysia-Malaysia Office, Petaling Jaya, Selangor, Malaysia.

[15] Muslim Aid Malaysia (2017) Report on Water for Life Project 2016/2017 at Peat Swamp Forest, Ayer Hitam Forest Reserve (N), Johor. Muslim Aid Malaysia, Kuala Lumpur.

[16] ISO (International Organization of Standards) (1980) ISO 1438/1-1980(E). Water Flow Measurement in Open Channels Using Weirs and Venturi Flumes-Part 1: Thin Plate Weirs. 1980. Global Engineering Documents. http://global.ihs.com

[17] Kindsvater, C.E. and Carter, R.W. (1959) Discharge Characteristics of Rectangular Thin Plate Weirs. Transactions of American Society of Civil Engineers, 124, Paper No. 3001. https://doi.org/10.1061/TACEAT.0007696 